\title{
SOLUBILITY OF BORON AND CARBON IN $\gamma$-IRON OF Fe-B-C ALLOYS
}

\author{
N.Yu. Filonenko* , A.N. Galdina ${ }^{* *}$ \\ "State Institution “Dnipropetrovsk Medical Academy of the Ministry of Health of Ukraine”, Dnipro, \\ Ukraine \\ ** Oles Honchar Dnipro National University, Dnipro, Ukraine \\ *e-mail:natph2016@gmail.com
}

It is known that solubility of elements affects the phase composition of alloys that are formed in the solidification process. To predict the phase composition of alloys, it is necessary to determine the solubility limit in the phases. In the paper the structural properties of austenite of alloys in the system of Fe-B-C are studied and the solubility limit of boron and carbon is determined. The investigation is carried out for the specimens with carbon content of 0.0001-2.3 wt.\% and boron content of 0.0001-1.0 wt.\%, the rest is iron. To determine the physical properties of alloys, we use the microstructure analysis, $X$-ray microanalysis, $X$ ray structure analysis and differential thermal analysis. It is shown experimentally that the maximum shift of the eutectoid point is observed when boron content is up to $0.004 \mathrm{wt} . \%$. When boron content of the alloy increases to $0.01 \mathrm{wt} . \%$, the eutectoid point shifts to the left to $0.21 \mathrm{wt} \%$-carbon and the austenite area decreases. Further increase in the numerical value of boron content in the alloy is hardly caused the eutectoid point to shift. In this paper, the vertical section of the Fe-B-C system state diagram is obtained from experimental data.

For the first time we obtain temperature dependence of the free energy of $\gamma$-iron solid solution, using the quasi-chemical method, and determine the solubility limit of carbon and boron. The maximum weight fraction of boron in the austenite can be up to $0.0136 \mathrm{wt} . \%$, and that for carbon - up to $1.12 \mathrm{wt} \%$.

Keywords: austenite, solubility of boron and carbon, Fe-B-C alloys.

Received 07.09.2019; Received in revised form 8.10.2019; Accepted 15.10.2019

\section{Introduction}

As it is known, solubility of boron in the austenite of alloys of Fe-B system is low and equals $0.0001 \mathrm{wt} . \%$ at the temperature of $1423 \mathrm{~K}$ according to the results of Ref. [1]. The authors of works $[2,3]$ note that at $1174^{\circ} \mathrm{K}$ the solubility of boron in the austenite is up to $0.15 \mathrm{wt} . \%$. In [2] the numerical value of solubility is indicated to be $0.0165 \mathrm{wt} . \%$ at $1413 \mathrm{~K}$. The authors of [4] give the data that at the temperatures of $1183 \mathrm{~K}$ and $1423 \mathrm{~K} 0.008$ and 0,025 atom.\% of boron are dissolved, correspondingly. In [5] it is stated that $0.021 \mathrm{wt} . \%$ of boron is dissolved in $\gamma$-iron at $1422 \mathrm{~K}$, and $0.009 \mathrm{wt} \%$ of boron - at $1179 \mathrm{~K}$. Such a difference in the values of solubility of boron in the austenite can be explained by the presence of impurities in the alloys $[2,5]$.

It is known that the maximum solubility of carbon in $\gamma$-iron for the system of $\mathrm{Fe}-\mathrm{C}$ is $2.14 \%$ at the temperature of $1420 \mathrm{~K}$ [6-7].

The investigation of the effect of boron doping of Fe-C alloys demonstrates that at low boron content the austenite region in the state diagram shrinks [8-13].

In the vertical section of the Fe-B-C state diagram suggested by authors of [9-11] it is shown that the eutectoid point is shifted continuously from $0.8 \mathrm{wt} . \%$ to the lower carbon content at the boron content ranged from $0 \%$ to $0.01 \%$, correspondingly, and down in temperature of austenite formation.

Thus, at present there is no unequivocal information on the solubility of boron and carbon in the austenite of alloys of Fe-B-C system.

The purpose of this paper is to determine the solubility limit of boron and carbon in $\gamma$-iron of Fe-B-C system alloys.

\section{Materials and methods}

The investigation was performed for the specimens with carbon content of $0.0001-2.3$ wt.\%, the rest was iron. To obtain Fe-B-C alloys the following constituents were used: carbonyl iron (with iron content of $99.95 \mathrm{wt} \%$ ), amorphous boron (with boron content 
of $97.5 \mathrm{wt} . \%$ ), graphite (with carbon content of $99.96 \mathrm{wt} . \%$ )). Smelting of specimens was performed in a Tammann furnace in alundum crucibles in argon atmosphere. The cooling rate of alloys was $10 \mathrm{~K} / \mathrm{s}$. To determine the chemical composition of alloys, chemical and spectral analyses were used [14]. To ascertain the peculiarities of the phase transformations for Fe-B alloys, the differential thermal analysis of the specimens was carried out by means of a derivatograph.

The phase composition of alloys was determined by X-ray microanalysis by means of JSM-6490 microscope with ASID-4D scanning head and "Link Systems 860" software energy-dispersive X-ray microanalyser, as well as by means of optical microscope "Neophot-21". X-ray electron probe analysis was carried out using internal standards. The X-ray and X-ray diffraction analyses were performed with DRON-3 diffractometer in monochromated $\mathrm{Fe}-\mathrm{K}_{\alpha}$ radiation.

\section{Results and discussion}

For Fe-C alloys with carbon content from $0.2 \mathrm{wt} . \%$ to $0.6 \mathrm{wt} . \%$ the microstructure and phase composition correspond to the commonly used state diagram [6-7].
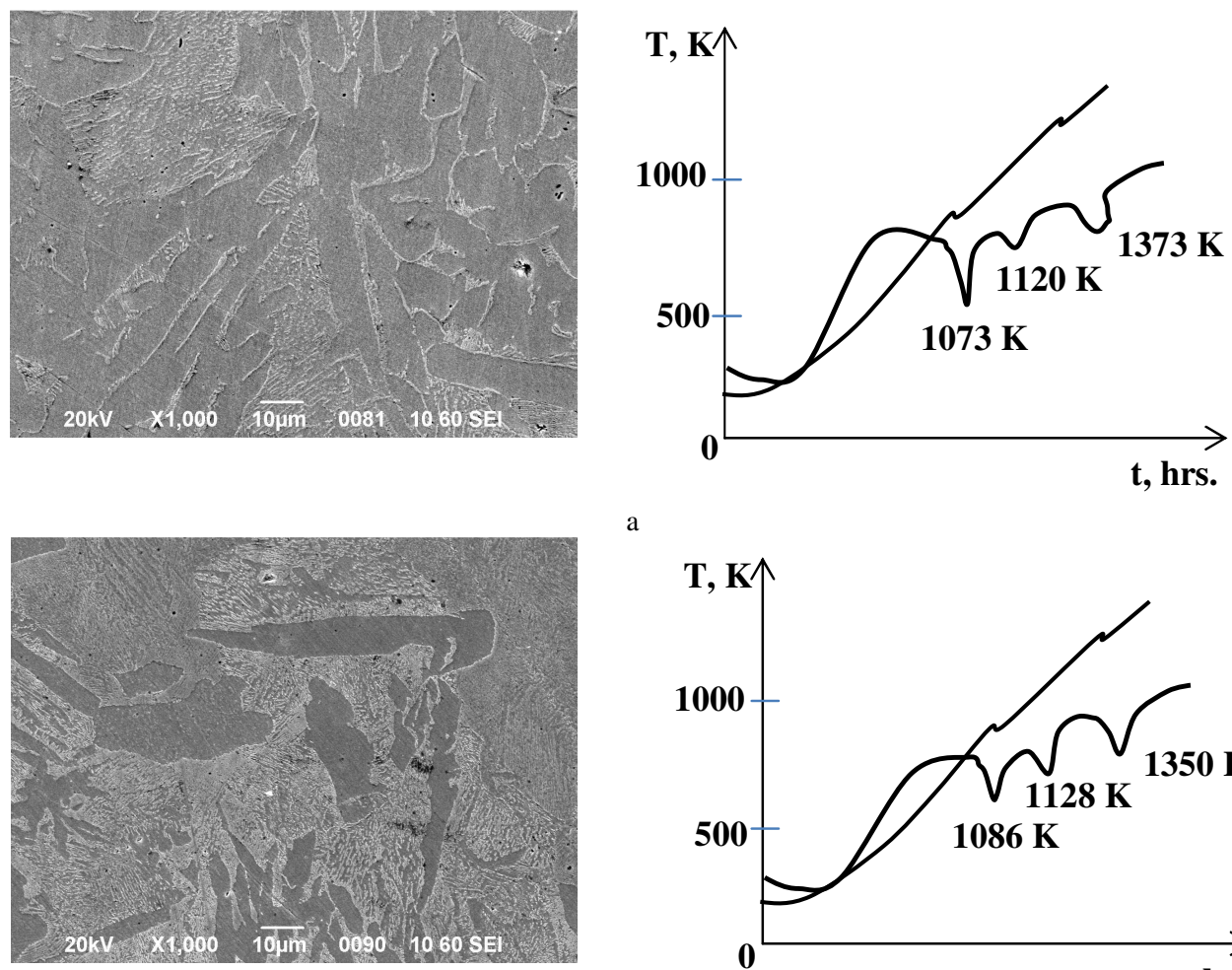

a

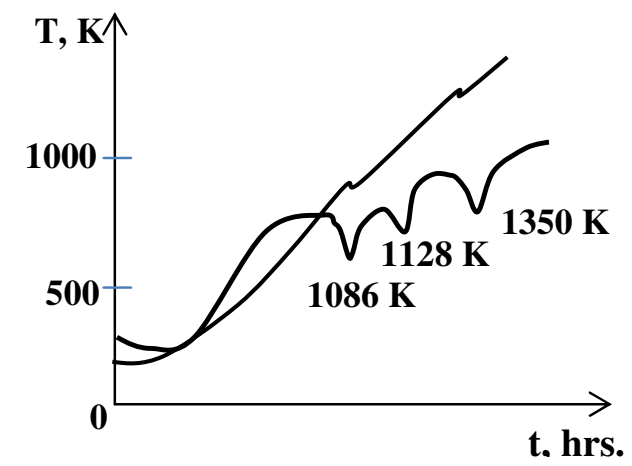

Fig. 1. The microstructure and curves of differential thermal analysis of the alloys with carbon content of 0.25 wt.\% and boron content of: 0.002 wt.\% (a), 0.004 wt.\% (b).

The boron doping of the alloys of Fe-C system leads to decreasing the austenite region and the eutectoid point shifting in the diagram to the left [8-9]. The maximum shift of the eutectoid point is observed at boron content up to $0.004 \mathrm{wt} . \%$. Further increase in the numerical value of boron content in the alloy results in shift of the eutectoid point, but slower (Fig. 1). 
For the alloy with carbon content of $0.25 \mathrm{wt} . \%$, when boron content is increased up to $0.002 \mathrm{wt} . \%$, the volume fraction of pearlite is increased to $60 \%, \alpha \rightarrow \gamma$ transformation occurs at the temperature of $1073 \mathrm{~K}$, and $\gamma \rightarrow \mathrm{L}$ transformation takes place at $1373 \mathrm{~K}$. Increasing the boron content in the alloy up to $0.01 \mathrm{wt} . \%$ is accompanied by an increase in the temperature of $\alpha \rightarrow \gamma$ transformation up to $1187 \mathrm{~K}$, and the temperature of $\gamma \rightarrow \mathrm{L}$ transformation rises up to $1277 \mathrm{~K}$.

Further increase in boron content does not affect the volume fraction of pearlite and the temperature of $\alpha \rightarrow \gamma$ transformation.

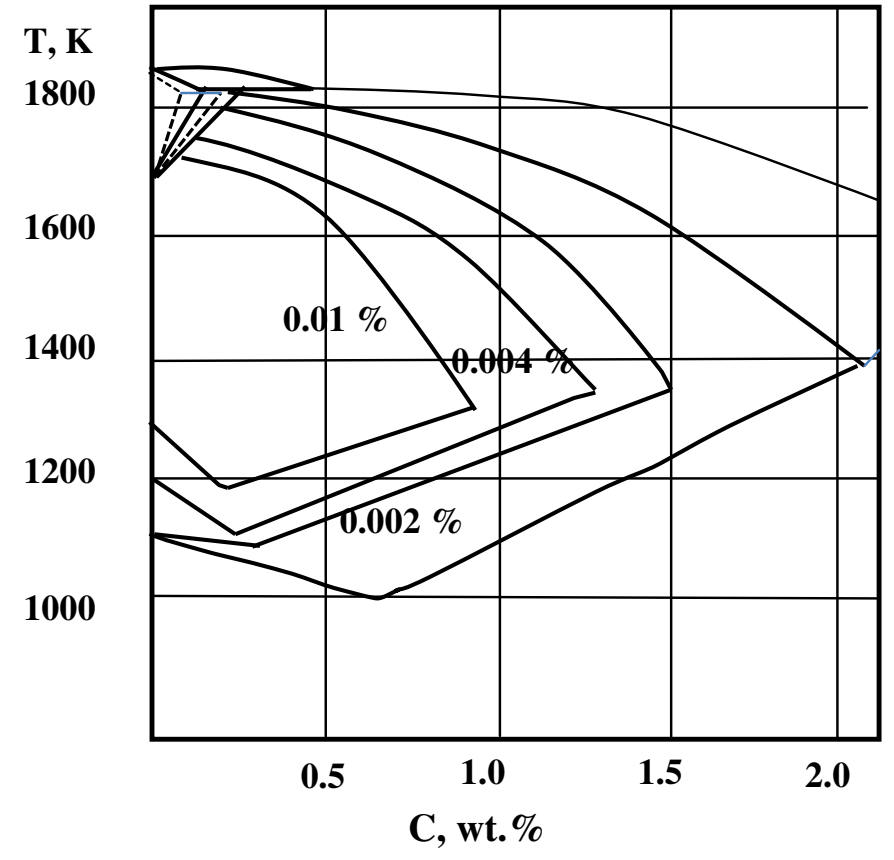

Fig. 2. Vertical section of the Fe-B-C system state diagram.

Thus, doping of iron-based alloys leads to shift of the eutectoid point to the left and to the decrease of the austenite region of the Fe-B-C system state diagram (Fig. 2). When boron content of alloy is increased up to $0.01 \mathrm{wt} . \%$, the eutectoid point shifts to $0.21 \mathrm{wt} . \%$-carbon and the austenite area shrinks.

The vertical section of the Fe-B-C state diagram obtained in this paper is in agreement with the results given in [9-11].

To determine and predict the phase transformations and phase composition in Fe-B$\mathrm{C}$ alloys in dependence on boron and carbon content, it is necessary to calculate the solubility limit of boron and carbon as a function of temperature.

The face-centered cubic crystal lattice of austenite contains octahedral and tetrahedral interstices (Fig. 3). The coordination number for the fcc lattice is 12. The elementary cell of the fcc lattice accounts for 4 atoms. It is possible to inscribe a sphere with radius of $0.41 r$ in the octahedral interstice. The boron atom located in octahedral interstice is surrounded by 6 neighbor iron atoms. The iron atoms are located at the distance of $a / 2$ from the boron atoms, where $a$ is lattice parameter of $\gamma$-iron. In tetrahedral interstice the boron atom is surrounded by 4 nearest iron atoms located at the distance of $a \sqrt{3} / 4$. In the tetrahedral interstice we can put a sphere with radius of 
$0.22 r$. For every atom of an elementary cell there is one octahedral void and two tetrahedral ones [15].

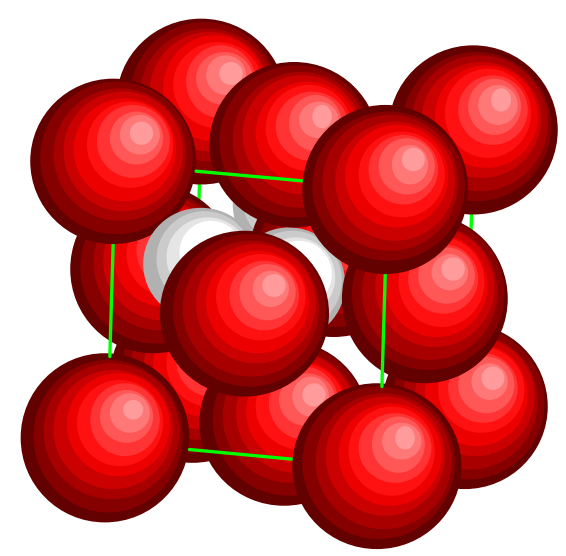

Fig. 3. Austenite crystal lattice.

To obtain free energy of the austenite, we apply the quasichemical method [16].

Let us denote the number of boron atoms in octahedral interstice as $N_{\mathrm{B}}$, the number of carbon atoms as $N_{\mathrm{C}}$, the number of vacancies as $N_{\mathrm{V}}$, and those numbers for tetrahedral interstice as $N_{\mathrm{B}_{1}}, N_{\mathrm{C}_{1}}$ and $N_{\mathrm{V}_{1}}$, respectively. The interaction of atoms can be considered as follows: for atoms of octahedral pore the energy of interaction for pairs of atoms Fe-C, Fe-B and Fe-V is denoted as $v_{\mathrm{FeC}}, v_{\mathrm{FeB}}, v_{\mathrm{FeV}}$. The interaction energy between atoms at the distance of $a \sqrt{3} / 4(\AA)$ is $v_{\mathrm{FeB}_{1}}, v_{\mathrm{FeV}_{1}}, v_{\mathrm{FeC}_{1}}$.

The number of tetrahedral pores in the fcc lattice is $2 N$ and that in the octahedral interstices is $N$, correspondingly. The free energy of the phase is determined as

$$
\begin{aligned}
F= & -6\left(N_{\mathrm{Fe}} N_{\mathrm{B}} v_{\mathrm{FeB}}+N_{\mathrm{Fe}} N_{\mathrm{C}} v_{\mathrm{FeC}}+N_{\mathrm{Fe}} N_{\mathrm{V}} v_{\mathrm{FeV}}\right)-4\left(N_{\mathrm{Fe}} N_{\mathrm{B}_{1}} v_{\mathrm{FeB}_{1}}+N_{\mathrm{Fe}} N_{\mathrm{C}_{1}} v_{\mathrm{FeC}_{1}}+\right. \\
& \left.+N_{\mathrm{Fe}_{1}} N_{\mathrm{V}_{1}} v_{\mathrm{FeV}_{1}}\right)-k T\left(1 2 ( N _ { \mathrm { B } } + N _ { \mathrm { C } } + N _ { \mathrm { V } } ) \left(\operatorname { l n } \left(N_{\mathrm{B}}+N_{\mathrm{C}}+\right.\right.\right. \\
& \left.\left.+N_{\mathrm{V}}\right)-1\right)-6 N_{\mathrm{B}}\left(\ln N_{\mathrm{B}}-1\right)-6 N_{\mathrm{C}}\left(\ln N_{\mathrm{C}}-1\right)-6 N_{\mathrm{V}}\left(\ln N_{\mathrm{V}}-1\right)- \\
& +4\left(N_{\mathrm{B}_{1}}+N_{\mathrm{C}_{1}}+N_{\mathrm{V}_{1}}\right)\left(\ln \left(N_{\mathrm{B}_{1}}+N_{\mathrm{C}_{1}}+N_{\mathrm{V}_{1}}\right)-1\right)-4 N_{\mathrm{B}_{1}}\left(\ln N_{\mathrm{B}_{1}}-1\right)- \\
& \left.-4 N_{\mathrm{C}_{1}}\left(\ln N_{\mathrm{C}_{1}}-1\right)-4 N_{\mathrm{V}_{1}}\left(\ln N_{\mathrm{V}_{1}}-1\right)\right) .
\end{aligned}
$$

To calculate the solubility of boron in $\gamma$-iron, we should find solution of the system of equations:

$$
\frac{\partial F}{\partial N_{\mathrm{Fe}}}=0, \frac{\partial F}{\partial N_{\mathrm{C}}}=0, \frac{\partial F}{\partial N_{\mathrm{C}_{1}}}=0, \frac{\partial F}{\partial N_{\mathrm{B}}}=0, \frac{\partial F}{\partial N_{\mathrm{B}_{1}}}=0, \frac{\partial F}{\partial N_{\mathrm{V}}}=0, \text { and } \frac{\partial F}{\partial N_{\mathrm{V}_{1}}}=0 .
$$

The obtained set of equations (2) is transcendental. Usually the solution of such equations can be obtained graphically or numerically. But within this problem there is a good reason to consider an asymptotic solution of the equations. For this we write the logarithm appeared in each equation of the system (2) as Taylor expansion (this is admissible in accordance with its convergence conditions):

$$
\begin{aligned}
& \frac{\partial F}{\partial N_{\mathrm{C}}}=-6 N_{\mathrm{Fe}} v_{\mathrm{FeC}}-6 k T\left(2 \ln \left(N_{\mathrm{B}}+N_{\mathrm{V}}\right)+\sum_{n=1}^{\infty} \frac{(-1)^{n+1}}{n}\left[\frac{2 N_{\mathrm{C}}^{n}}{\left(N_{\mathrm{B}}+N_{\mathrm{V}}\right)^{n}}-\left(N_{\mathrm{C}}-1\right)^{n}\right]\right)=0 \\
& \frac{\partial F}{\partial N_{\mathrm{C}_{1}}}=-4 N_{\mathrm{Fe}} v_{\mathrm{FeC}_{1}}-4 k T\left(\ln \left(N_{\mathrm{B}_{1}}+N_{\mathrm{V}_{1}}\right)+\sum_{n=1}^{\infty} \frac{(-1)^{n+1}}{n}\left[\frac{N_{\mathrm{C}}^{n}}{\left(N_{\mathrm{B}_{1}}+N_{\mathrm{V}_{1}}\right)^{n}}-\left(N_{\mathrm{C}_{1}}-1\right)^{n}\right]\right)=0
\end{aligned}
$$




$$
\begin{aligned}
& \frac{\partial F}{\partial N_{\mathrm{B}}}=-6 N_{\mathrm{Fe}} v_{\mathrm{FeB}}-6 k T\left(2 \ln \left(N_{\mathrm{C}}+N_{\mathrm{V}}\right)+\sum_{n=1}^{\infty} \frac{(-1)^{n+1}}{n}\left[\frac{2 N_{\mathrm{B}}^{n}}{\left(N_{\mathrm{C}}+N_{\mathrm{V}}\right)^{n}}-\left(N_{\mathrm{B}}-1\right)^{n}\right]\right)=0 \\
& \frac{\partial F}{\partial N_{\mathrm{B}_{1}}}=-4 N_{\mathrm{Fe}} v_{\mathrm{FeB}_{1}}-4 k T\left(\ln \left(N_{\mathrm{C}_{1}}+N_{\mathrm{V}_{1}}\right)+\sum_{n=1}^{\infty} \frac{(-1)^{n+1}}{n}\left[\frac{N_{\mathrm{B}_{1}}^{n}}{\left(N_{\mathrm{C}_{1}}+N_{\mathrm{V}_{1}}\right)^{n}}-\left(N_{\mathrm{B}_{1}}-1\right)^{n}\right]\right)=0 \\
& \frac{\partial F}{\partial N_{\mathrm{V}}}=-6 N_{\mathrm{Fe}} v_{\mathrm{FeV}}-6 k T\left(2 \ln \left(N_{\mathrm{B}}+N_{\mathrm{C}}\right)+\sum_{n=1}^{\infty} \frac{(-1)^{n+1}}{n}\left[\frac{2 N_{\mathrm{V}}^{n}}{\left(N_{\mathrm{B}}+N_{\mathrm{C}}\right)^{n}}-\left(N_{\mathrm{V}}-1\right)^{n}\right]\right)=0 \\
& \frac{\partial F}{\partial N_{\mathrm{V}_{1}}}=-4 N_{\mathrm{Fe}} v_{\mathrm{FeV}_{1}}-4 k T\left(\ln \left(N_{\mathrm{B}_{1}}+N_{\mathrm{C}_{1}}\right)+\sum_{n=1}^{\infty} \frac{(-1)^{n+1}}{n}\left[\frac{N_{\mathrm{V}_{1}}^{n}}{\left(N_{\mathrm{B}_{1}}+N_{\mathrm{C}_{1}}\right)^{n}}-\left(N_{\mathrm{V}_{1}}-1\right)^{n}\right]\right)=0 .
\end{aligned}
$$

In this paper we consider the case when boron and carbon atoms penetrate the $\gamma$-iron lattice. The choice of such an approach is due to the fact that at present the boron position in the $\gamma$-iron lattice is not unanimous. There is an opinion only on the interstitial position of boron atoms in the austenite lattice; the other opinion is the substitutional position of iron atoms in the lattice or interstitial-substitutional one. It should be noted that more interesting and appropriate task is to determine the solubility of boron in the interstitial position and its effect on the solubility of carbon. In addition, the binding energy between boron and iron atoms will be greater in numerical value at the interstitial position [17].

To obtain an asymptotic estimate of the system (2) solution, it is quite sufficient to consider the first two terms of the logarithm expansion.

The result of performed calculations is that the maximum boron content in the austenite may be up to $0.0136 \mathrm{wt} . \%$ and that for carbon is $1.12 \mathrm{wt} . \%$.

The obtained results on the solubility of boron and carbon in $\gamma$-iron reveal smaller numerical values in comparison with solubility in corresponding binary systems. This result is obtained provided that the $\gamma$-iron lattice is free of defects. It is known that boron is a horophilic element and interacts more actively with structural defects [18]. This can explain the difference between our findings and the results of the solubility of boron and carbon obtained experimentally. The analysis of outcomes reveals that boron doping of $\mathrm{Fe}-\mathrm{C}$ alloys leads to the decrease of the carbon content in the austenite, which may be a reason of shift of the eutectoid point to the left in the Fe-C state diagram and increase in the volume fraction of pearlite. In addition, carbon atoms are probably energetically more favorable to be surrounded by iron atoms than by boron ones.

\section{Conclusions}

The investigation was performed for the specimens with carbon of 0.0001-2.3 wt.\% and boron content of $0.0001-1.0 \mathrm{wt} . \%$, the rest was iron. It is shown experimentally that the maximum shift of the eutectoid point is observed at boron content up to $0.004 \mathrm{wt} . \%$. When boron content in the alloy rises up to $0.01 \mathrm{wt} . \%$, the shift of the eutectoid point to the left up to carbon content of $0.21 \mathrm{wt} . \%$ occurs and the austenite region shrinks. Further increase in the numerical value of boron content is hardly caused the shift of the eutectoid point. In this paper we obtained the vertical section of the Fe-B-C system state diagram based on experimental data.

For the first time applying the quasi-chemical method, we obtain temperature dependence of the free energy for $\gamma$-iron solid solution and determine the solubility limit of carbon and boron depending on temperature. The maximum weight fraction of boron in the austenite can be up to $0.0136 \mathrm{wt} . \%$ and that for carbon is $1.12 \mathrm{wt} . \%$, which enables 
to predict the phase composition of alloys depending on the boron and carbon content in the alloy.

\section{References}

1. Khansen, M. Struktury dvoynykh splavov / M. Khansen, K. Anderko. - Moscow: Metallurgizdat, 1962. - 1488 p.

2. Samsonov, G.V. Boridy / G.V. Samsonov, T.I. Serebryakova, V.A. Neronov. Mocsow: Atomizdat, 1975. - $331 \mathrm{p}$.

3. Lyakishev, N.P. Borsoderzhaschie stali i splavy / N.P. Lyakishev, Yu.L. Pliner, S.I. Lappo. - Moscow: Metallurgiya, 1986. - 191 p.

4. Lyakishev, N.P. Diagrammy sostoyaniya dvoinykh metallicheskikh sistem: Spravochnik. Vol. 1 / N.P. Lyakishev. - Moscow: Mashinostroyeniye, 1996. - 992 p.

5. Portnoy, K.I. State diagram of iron-boron system / K.I. Portnoy, M.Kh. Levinskaya, V.M. Romashov // Metal Powder Industry. - 1969. - No. 8(80). - P. 66-69.

6. Gulyaev, A.P. Metallovedenie / A.P. Gulyaev, A.A. Gulyaev. - Moscow: Alyans, 2011. -644 p.

7. Arzamasov, B.N. Materialovedeniye / B.N. Arzamasov, V.I. Makarova, G.G. Mukhin et al. - Moscow: Izd-vo MGTU im. N.E. Baumana, 2001. - 648 p.

8. Hasebe, M. Thermodynamic analysis of ternary Fe-C-B system / M. Hasebe and T. Nishizawa // Journal of the Japan Institute of Metals and Materials. -1974. - Vol. 38, No. 1. - P. 46-54.

9. Ohtani, H. Calculation of Fe-C-B Ternary Phase Diagram / H. Ohtani, M. Hasebe, T. Nishizawa // Transactions ISIJ. - 1988. -Vol. 28. - P. 1043-1050.

10. Tammann, G. Ueber die Grenzen des festen Zustandes. I, II, III, IV, V. / G. Tammann // Annalen Der Physik Und Chemie. - 1897. - Vol. 298, Issue 10. - P. 280 299; 1898. - Vol. 302, Issue 11. - P. 473-498; 1899. - Vol. 304, Issue 8. - P. 629-657; 1900. - Vol. 307, Issue 5. - P. 1-31; 1900. - Vol. 308, Issue 10. - P. 161-194.

11. Kineko, H. Borides and Carbides in the System of Fe-B-C / H. Kaneko, T. Nishizawa and A. Chiba // Journal of the Japan Institute of Metals and Materials. - 1966. - Vol. 30, Issue 3. - P. 263-267.

12. Fu H. A Study of the Quenching Structures of Fe-B-C Alloy/l Materialwissenschaft Und Werkstofftechnik. - 2007. - Vol. 38, Issue 4. - P. 299-302.

13. Novikov, M.M. Osoblyvosti borydnykh faz u vuglecevykh stayakh, scho mistyat' bor / I.M. Spiridonova, M.M. Novikov, N.Yu. Filonenko // Visnyk Kyivs'kogo universytetu. Seria Fizyko-matematychni nauky. - 2006. - No. 3. - P. 525-530.

14. Tverdokhlebova, S.V. Spectrometry of the boron-containing alloys / S.V. Tverdokhlebova // Visnyk Dnipropetrovskogo universitetu. Serija Fizika. Radioelektronika. - 2007. - Vol. 14(12/1). - P. 100-104.

15. Shaskolskaya, M.P. Kristallografiya / M.P. Kristallografiya. - Moscow: Vysshaya shkola, 1984. - $376 \mathrm{p}$.

16. Kozheurov, V.A. Statisticheskaya termodinamika / V.A. Kozheurov. - Moscow Metallurgiya, 1975. - $175 \mathrm{p}$.

17. Filonenko, N.Yu. Vplyv vmistu karbonu na typ tverdogo rozchynu v splavakh na zaliznii osnovi / N.Yu. Filonenko, A.S. Baskevich, V.V. Sobolev // Nakovyi Visnyk Natsionalnoho Hirnychoho Universytetu. - 2012. - No. 4. - P. 74-78.

18. Gavrylova, V.G. O tipe rastvoreniya bora v austenite i ego vzaymodeistvie s dislokatsiyami / V.G. Gavrylova, I.F. Tkachenko, A.V. Belostochnyi // Metaloznavstvo ta termichna obrobka metaliv. - 1999. - No. 4. - P. 56-58. 